outlines a correspondence between the activity of the interstitial cells of Leydig in the testis and the inception of the great sexual occurrences in ontogeny, the determination of sex and the acquirement of functional activity. Yet he says that at bivth there was " plenty of evidence of nuclear mitosis, and I came to the conclusion that numbers of the cells had attained maturity and were on the way to a regressive atrophy." At puberty the cells of Leydig reappear, after " commencing manifestations of nuclear activity and karyokinetic figures " at eleven years. What ontogenic event coincides, then, with the "maturity" of these cells at birth ?

It is evident that we know far too little of the histological appearances of the endocrine glands at successive ages in the normal animal, and of their influence upon the body functions at different periods or at any period of life. But Sir Frederick Mott is to be congratulated upon a continuity of effort in the elucidation of a baffling problem. It is to be hoped that his great labours, no less than the eminence of his advocacy, will encourage a more concerted attack upon the manifold problems of mental fitness.

\section{The French Congress of Industrial Chemistry.}

THE fifth French Congress of Industrial Chemistry was opened at Paris on October 4, under the auspices of the Société de Chimie Industrielle, and was organised in conjunction with the Exposition Internationale des Arts Décoratifs at the Grand Palais and with the centenary of Chevreul's discoveries of the nature of fats and his manufacture of the stearine candle. The Congress was preceded by a series of non-technical addresses on the applications of chemistry to a number of industries, and by a reception at the Grand Palais. The formal opening of the Congress on October 5 was presided over by Monsieur de Monzie, the Minister of Public Instruction; it included an address by Sir Robert Hadfield on his own recollections of metallurgy in France. The Congress then resolved itself into sixteen sections, in each of which important papers on many branches of chemical industry were read and discussed. The official banquet was held at the Palais d'Orsay, the chair being taken by Monsieur E. Borel, Minister for the Marine, and the formal adjournment of the Congress took place on October 8 under the presidency of Monsieur C. Chaumet, Minister of Commerce. The following two days were spent in visits to works, one group of those present inspecting factories in the neighbourhood of Paris and a second travelling to Grenoble to visit the international exhibition of water-power and works in the vicinity.

The celebration of the discoveries of Chevreul on fats and oils was held at the National Museum of Natural History, in which Chevreul did his work, on Sunday, October II. The place of honour was taken by the President of the French Republic, Monsieur Doumergue, and, after a number of short speeches, Prof. Henry E. Armstrong delivered an appreciation of the work of Chevreul and its consequences; the silver gilt medal of the Société de Chimie Industrielle was presented to Prof. Le Chatelier and to Prof. Armstrong. The proceedings terminated in a banquet at the Club, which was during the War the Cercle Interallie and is now La Bienvenue Française. The British delegates to the Congress included Prof. Armstrong, Mr. E. C. Evans, Prof. C. S. Gibson, Mr. A. J. Greenaway, Sir Robert Hadfield, Mr. E. A. Hailwood, Sir Frederick Nathan, Sir W. J. Pope, Dr. S. Miall, Mr. A. R. Smith and Mr. E. A. Umney.
One of the most striking features of this very successful Congress, in addition to the admirable manner in which it was organised and fitted in with the exhibition and the Chevreul centenary, was the fact that quite a number of Cabinet ministers took an active and even an enthusiastic part in the proceedings. Each of these gentlemen, when he spoke, showed a clear appreciation of the importance of pure science and of its applications to industry; it is an unfortunate fact that we cannot imagine a number of Cabinet ministers taking an active and appreciative part in a congress of applied chemistry in Great Britain.

$$
\text { W. J. P. }
$$

\section{University and Educational Intelligence.}

CAMBRIDGE.-Lists of candidates who have passed the recent First and Second Examinations for Medical and Surgical Degrees have appeared. In the First Examination lists the number of those who satisfied the examiners before matriculating-which in most cases means that they received the necessary instruction at school-is large; the percentages of nonmatriculated candidates on the several pass lists being: Pt. I (Chemistry), 60 per cent. ; Pt. 2 (Mechanics), 80 per cent.; Pt. 3 (Physics), 67 per cent.; Pt. 4 (Biology), 4o per cent. More of these candidates take the examinations in October than at any other season of the year, but the figures quoted emphasise the fact that, while most of the public schools make it their business to prepare boys for the chemistry and physics, not a few are now also able to do so in biology.

Authorisation has been granted for the following reappointments: Dr. Duckworth (reader in human anatomy) ; Prof. W. E. Dixon (reader in pharmacology); Mr. S. W. Cole (lecturer in medical chemistry); Dr. T. S. Hele and Dr. F. J. W. Roughton (lecturers in biochemistry); Dr. Shillington Scales (lecturer in medical radiology and electrology).

The following have been elected to fellowships at Trinity College: Prof. G. E. Moore, Mr. A. S. F. Gow, Mr. R. V. Southwell, Mr. P. W. Duff, Dr. J. A. Chadwick, Mr. H. O. Evennett, Dr. P. Kapitza.

At Corpus Christi College Mr. T. R. B. Sanders has been appointed lecturer in engineering, while Mr. C. H. E. Smyth and Mr. R. A. Butler have been elected fellows.

At Emmanuel College the following have been awarded Research Studentships: Mr. E. G. Lewis (External), Mr. G. E. Hutchinson (Honorary), and Mr. C. Rimington, whilst grants for research have been made to Mr. A. Sopwith, Mr. W. L. Cuttle, and Mr. R. A. R. Hartridge.

The following reappointments have been made: Mr. J. T. Saunders, fellow and tutor of Christ's College, to be demonstrator of animal morphology; Mr. H. H. Brindley to be demonstrator of biology to medical students.

The Lees Knowles Lectures on military science are to be given by Maj.-Gen. Sir Frederick Maurice, K.C.M.G., whose subject will be "Statesmen and Soldiers in the American Civil War."

The degree of Doctor of Science honoris causa is to be conferred on Sir Edgeworth David, professor of geology at the University of Sydney. There is a pleasant rumour abroad to the effect that Sir David intends to spend some weeks in Cambridge in the near future.

EDINBURGH.-The following changes in the staff have recently taken place: Prof. J. Shield Nicholson has resigned the chair of political economy, which he has held for forty-five years; Prof. Godfrey $\mathrm{H}$. Thomson has taken up duty as professor of education in succession to the late Prof. A. Darroch; Mr. A. D. 